This is the accepted version of the following article: McMahon, Lance and Phillimore, John. 2013. State and territory government strategic plans: Exercises in managing, monitoring and marketing. Australian Journal of Public Administration. 72 (4): pp. 404-418., which has been published in final form at http://doi.org/10.1111/1467-8500.12041

\title{
State and Territory Government Strategic Plans: Exercises in Managing, Monitoring and Marketing
}

\author{
Lance McMahon, Curtin University \\ John Phillimore, Curtin University
}

\begin{abstract}
All but three of the Australian States and Territories have whole-of-government, jurisdiction-wide strategic plans in place and the three exceptions had previously established a state plan in the decade after the first such plans were introduced by Tasmania and Victoria in 2001. Scholarly attention to date has been directed towards discrete aspects of state plans, such as the extent to which they can be seen as exercises in participative democracy or sustainability, rather than with examining state plans for what they explicitly purport to be - strategic plans originating in the core executive of government. We propose that there are three key strategic orientations for Australian state plans: to holistically manage, monitor and market government administration. These orientations may be competing, complementary or overlapping, and can vary over time. The article also proposes that state plans are a significant development in public management and warrant further and more detailed examination.
\end{abstract}


At the close of the $20^{\text {th }}$ century, none of the Australian States or Territories had attempted to apply strategic planning to the whole-of-government and jurisdictionwide context. This was despite the fact that strategic plans had become almost universal in the individual agencies of State and Territory governments during the previous decade, as part of the New Public Management (NPM) trend. By the end of the first decade of the $21^{\text {st }}$ century, however, each of the States and Territories had endeavoured to put some form of a 'state plan' (as they are collectively called for brevity in this article) in place. Some of these plans have continued into the second decade, while others have been abandoned.

Explaining the advent of state plans in this relatively short period of time suggests several questions: what exactly are state plans, what were their origins, and to what purposes are they primarily orientated? These questions have not yet been comprehensively discussed in scholarly examination or media commentary. Typically, analysis to date has focused on either the process by which plans have been generated (in particular, the extent of community participation), or on the degree to which particular policy goals (such as sustainability) have been promoted. By contrast, we propose that state plans are best understood for what they present to be strategic planning tools of the core executive of government (Dunleavy and Rhodes 1990); in the context of this paper, we take this to be the Premier/Chief Minister and senior officials of central agencies acting with executive and co-ordinating authority.

As discussed below, state government planning models from the US were influential in the introduction of state plans into Australia with US academics such as Nutt and Backoff (1987) having long advocated widespread use of strategic approaches to government management practice. Another leading US academic commentator on state, local government, public sector and not-for-profit strategic planning has observed; '[s]trategic planning is not any one thing, but is instead an adaptable set of concepts, procedures, tools, and practices intended to help people and organizations figure out what they should be doing, how, and why' (Bryson 2010a:255). We see state plans as exercises in '[d]eliberative, disciplined effort to produce fundamental decisions and actions that shape and guide what an organization (or other entity) is (its identity), what it does (its strategies and actions), and why it does it (mandates, mission, goals, and the creation of public value)' (Bryson 2010a:256-257). Australian 
state plans also exhibit the broadly accepted key features of the strategic planning approach, namely that of having:

- A medium to long term planning horizon;

- The organisation of goals and outcomes into a rational hierarchy;

- A commitment and resources adequate for effective implementation; and

- A proactive approach to changes in conditions based on ongoing consultation and monitoring (Bozeman and Straussman 1990).

Strategic planning does not necessarily imply the practice of strategic management, as noted by leading commentators on public management such as Hughes (2003:142-44) among others, but it is a precondition. That is, strategic management cannot exist unless an effective strategic planning process has previously been put in place. It can be argued that the States with less detailed plans such as Western Australia (WA) and Queensland (QLD) were not committed to a path of strategic management, whereas plans with greater detail such as the current New South Wales (NSW) and South Australian (SA) ones are.

From a strategic planning perspective, state plans can be seen to have at least three distinct orientations (as shown in Figure 1). First is as a means for managing at a strategic level and in particular for facilitating cross-government co-ordination; second is as a means for monitoring government and state performance through measuring, auditing and reporting outputs and outcomes; and third is as a means for marketing the achievements of the government of the day in both the political 'spin' promotive sense and the communicative sense of providing the public with appropriate levels of information and paths for engagement. These orientations are not necessarily consistent or complementary, and the balance between them varies across jurisdictions and over time. To be effective, state plans need to achieve a balance between all three - too much emphasis on any one element causes problems in either the performance or perception of the plan, or both. 
Figure 1: State Plans - Strategic Purposes and Functions as Monitoring, Managing and Marketing

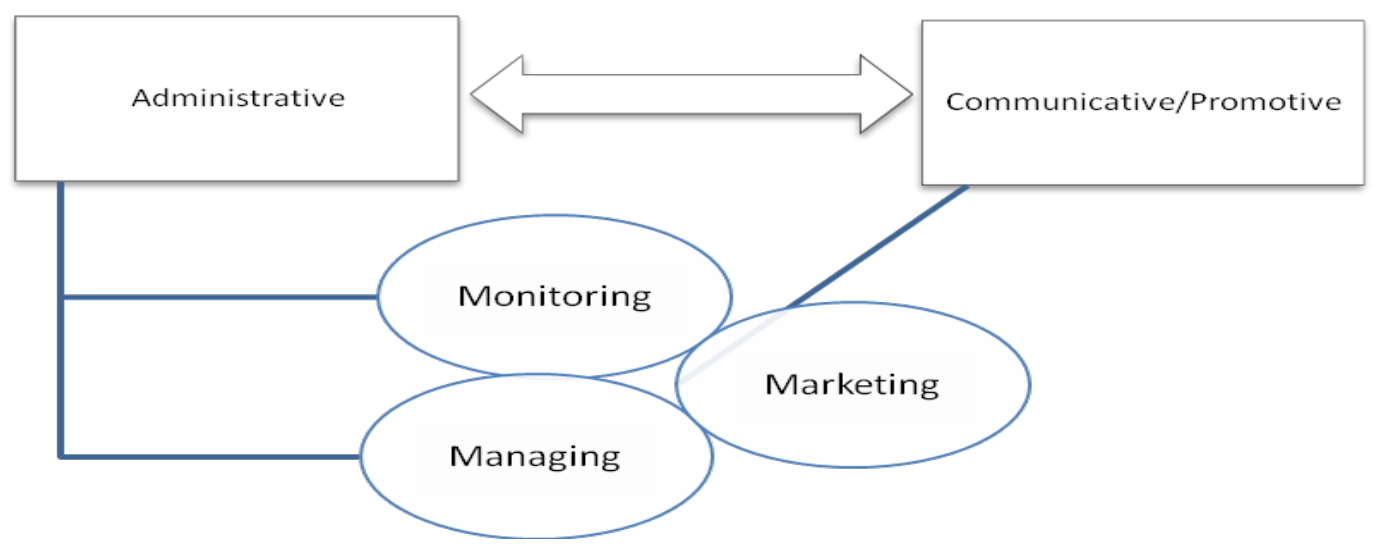

Even if governments get the balance 'right', however, it remains an open question whether state plans will necessarily have enduring strategic utility and be robust enough to survive political change, as all of the original state plans were initiated by Labor governments. However, the adoption of a new state plan by the new coalition government in NSW in September 2011 suggests that state plans may be more than just passing ephemera of Australian public policy and management.

\section{Existing literature on Australian state plans}

Despite being a nation-wide and on-going development in public management at State and Territory level, only a modest amount of academic examination has been directed towards state plans. Not surprisingly, the more detailed and longer lived plans of Tasmania (TAS) and Victoria (VIC) have been the subjects of most commentary and analysis (examples being Adams and Wiseman 2003; Crowley 2006, 2009; Crowley and Coffey 2007; Nabben 2011) with broader coverage of later adopters being limited to very few sources, for example Gallop (2007) and van Schoubroeck (2008, 2010). 
We identify three principal approaches to state plans that have been pursued in the existing academic literature: (i) as exercises in participative democracy; (ii) as opportunities to promote and practice sustainability; and (iii) as new governance tools.

\section{Participative Democracy}

Several examinations of state plans centre on the issue of the extent to which they can be seen as involving citizens in the process, through participative or deliberative democracy practises. Three states figure prominently in this approach - TAS, VIC and SA. Crowley's analysis of Tasmania Together (TT) finds it to be 'an innovation in Australian policy work' (Crowley 2006:152). In the context of deliberative democracy she finds it has had 'a novel impact for reconnecting public preferences with state policy-making and budgetary priorities' (Crowley 2009:1016) but that it has not led to more deliberative policy making or a move away from a representative political model.

Crowley and Coffey (2007a:34) look at TT and Growing Victoria Together (GVT) and find that TT 'is a bottom-up deliberative framework that is nevertheless strategically rational and in pursuit of clear objectives' and a 'reflection of community priorities’ while GVT 'is a rhetorical plan... to broadly measure policy progress’ and 'is a reflection of political priorities.' Also GVT 'is a more traditional top down' approach and 'not community owned or driven' (Crowley and Coffey 2007a:34) and is 'very much a political tool' (Crowley and Coffey 2007a:35).

Newell and Wilkinson (2003) find the consultation process used in TT marginalised disability groups while Nabben (2011) finds that GVT had disappointed as part of an 'opportunity lost' for a new era of community. Manwaring analyses the extent to which SA's plan involved consultative processes and finds it to be inadequate, noting it was ' ... highly managed with little real devolution of power. The consultation had a number of multiple and competing aims, blending promotion with consultation, legitimation and education' (Manwaring 2010:186).

\section{Sustainability}

A second approach in the literature has regarded state plans as changes in the policy focus of government, linked to the plans being commonly established early in the term of a new government or leader. Of particular note in the early state plans was the 
inclusion of sustainability as an explicit priority. TAS and VIC both included sustainability as a core objective of their state plans, as a conscious move away from economic rationalist approaches.

In their analysis of GVT, Adams and Wiseman (2003) argue that GVT balanced the requirements of economic competitiveness with social justice and environmental quality by offering a distinct alternative to the 'extreme end of market-based economics' that characterised the previous Kennett government (Adams and Wiseman 2003:12). Commenting on GVT, Coffey and Major find in 'broad terms, environmental sustainability is stated as a core element of the Government's policy directions’ (Coffey and Major 2005:32).

Crowley has written on several occasions about the potential for TT and GVT to embed environmental sustainability into policy planning and outcomes (Crowley 2006; Crowley and Coffey 2007a; 2007b) and observed with Coffey that TT and GVT 'are indeed very different attempts at setting state policy that do set out environmental, social and economic objectives.' (Crowley and Coffey 2007b:57) However, they observe tension in the way sustainability is treated between being 'balanced' or 'traded off' as opposed to 'integrated concerns across government' (Crowley and Coffey 2007a:32) and conclude that TT and GVT 'lack practical orientation towards environmental sustainability that needs attention if environmental decline is to be reversed and sustainability fostered' (Crowley and Coffey 2007a:57).

\section{New Governance Tools}

A third analytical approach has emphasised the role of state plans as new tools of governance, rather than focusing on the process by which they were written or the policy content of the plans themselves. Althaus (2008) looks at state plans through the lens of how governments manage political risk, contrasting 'traditional' policy analysis with political risk analysis and argues that the former perspective suggests that state plans are 'good image-makers but policy sleights of hand' while the latter suggests that state plans can 'all be viewed as political successes.' (Althaus 2008:137)

Althaus notes that the plans served to establish credentials in economic management unsullied by and distanced from reference to the record of previous Labor state governments and also to stamp a fresh impress on policy settings repudiating those of 
predecessor administrations and to cement the Premier's personal authority and vision. The plans identify the policy preferences of the electorate, to find remedies for problems identified, address needs and 'ensure that potential political dangers - such as losing control - were addressed and contained' (Althaus, 2008:143). Gallop argues that state plans provide an alternative to NPM by offering a whole of government approach (Gallop 2007) and notes that: '[n]ot only is the Government giving itself a sense of purpose by adopting the plan, it is also providing a framework of accountability for ministers and agencies’ (Gallop 2006).

\section{Discussion}

While the existing literature provides valuable perspectives on aspects of the state plans, they do not in our view capture the full essence of the phenomenon.

Deliberative democracy and sustainability were important aspects of several state plans, but they are not in themselves critical - it is possible to have a 'top down' plan and for it not to emphasise sustainability. Seeing plans as a governance tool is more promising as it connects more directly to the plans' initiators - the core executive and what they are trying to achieve through producing a state plan.

Building on this governance perspective and based on the viewpoint of the core executive as the initiator and final authoriser of the plans, our focus here is on what Premiers, Ministers, central agencies and senior bureaucrats seek from a state plan, what their function is and what role they play. An opening observation is that, unlike traditional agency-based strategic planning, they are whole-of-government strategic plans, initiated and driven by the core executive, which gives them a certain character - in particular, they emphasise the need for monitoring performance across the whole of government, ensuring that effective management leads to mandated achievements as well as having a political imperative to market those achievements - in other words, the three key strategic planning purposes of managing, monitoring and marketing.

\section{Overview of State Plans in Australia since 2001}

Commencing with TAS and VIC in 2001, every State and Territory government in Australia adopted a form of state plan by the end of the decade. Between 2001 and 2006, four states (TAS, VIC, SA and NSW) and the Australian Capital Territory 
(ACT) produced fully-fledged state plans. QLD produced a variant of the overarching plan document with its revamped Smart State strategy in 2005, while WA fashioned what were effectively two limited versions of a state plan in 2003 with two publications, the State Sustainability Strategy and Better Planning, Better Services. ${ }^{1}$ As Brueckner and Pforr (2011) have discussed, the enthusiasm for the nationally highly regarded sustainability strategy waned when Gallop retired from office and his Labor successor Carpenter adopted a more pro-development policy stance.

In 2009 the Northern Territory (NT) produced its own plan, thereby completing a clean sweep of States and Territories and leaving the Commonwealth as the only government in the federation not to have attempted such a plan, as most of Australia's 564 local governments are currently undertaking strategic planning processes as part of a nationally agreed policy, although not all have completed this process yet. By 2012, the fall of Labor governments had seen WA, VIC, QLD and NT abandon their plans. ${ }^{2}$ However, the new Liberal-National coalition government in NSW was an exception to this trend, as it adapted and revamped that state's strategic plan as NSW 2021 in 2011. In TAS, the Liberal-National opposition has a policy position to modify rather than abandon TT. In October 2012, the Giddings Labor government effectively adopted the Liberal policy by announcing it would repeal the legislation later that year, so as to remove the independent statutory TT Progress Board and bring the management of TT in-house to the Premier's Department as a cost saving measure. Table 1 provides a summary of the implementation and termination of the plans.

Table 1: Premiers/Chief Ministers Implementing and Terminating State Plans

\begin{tabular}{|l|l|l|l|l|}
\hline State/Territory & $\begin{array}{l}\text { Year Plan } \\
\text { Implemented/ } \\
\text { Updated }\end{array}$ & $\begin{array}{l}\text { Premier /CM } \\
\text { When Plan } \\
\text { Commenced/ } \\
\text { Terminated }\end{array}$ & $\begin{array}{l}\text { Party of } \\
\text { Premier/ } \\
\text { CM }\end{array}$ & Management \\
\hline TAS & 2001 & Bacon & ALP & $\begin{array}{l}\text { Independent Statutory Body 2001- } \\
\text { 2012, Premier's Department 2012 on. }\end{array}$ \\
\hline VIC & $\begin{array}{l}2001 \\
2011 \text { Ceased }\end{array}$ & $\begin{array}{l}\text { Bracks } \\
\text { Baillieu }\end{array}$ & $\begin{array}{l}\text { ALP } \\
\text { LIB }\end{array}$ & Premier's Department \\
\hline WA & 2003 & $\begin{array}{l}\text { Gallop } \\
\text { Barnett }\end{array}$ & $\begin{array}{l}\text { ALP } \\
\text { LIB }\end{array}$ & Premier's Department \\
\hline SA & 2008 Ceased & Rann & ALP & $\begin{array}{l}\text { Premier's Department/ } \\
\text { Cabinet Committee }\end{array}$ \\
\hline ACT & 2004 & Stanhope & ALP & Chief Minister's Department \\
\hline QLD & 2004 & $\begin{array}{l}\text { Beattie } \\
\text { Bligh }\end{array}$ & $\begin{array}{l}\text { ALP } \\
\text { ALP }\end{array}$ & Premier's Department \\
\hline
\end{tabular}




\begin{tabular}{|l|l|l|l|l|}
\hline & 2012 Ceased & Newman & LNP & \\
\hline NSW (1) & $\begin{array}{l}2006 \\
2010 \\
2011 \text { Ceased }\end{array}$ & $\begin{array}{l}\text { Iemma } \\
\text { Keneally } \\
\text { O'Farrell }\end{array}$ & $\begin{array}{l}\text { ALP } \\
\text { ALP } \\
\text { LIB }\end{array}$ & $\begin{array}{l}\text { Premier's Department/ } \\
\text { Dedicated Minister (2010-11)/ } \\
\text { Cabinet Committee }\end{array}$ \\
\hline NSW (2) & 2011 & O'Farrell & LIB & $\begin{array}{l}\text { Premier's Department/ } \\
\text { Cabinet Committee }\end{array}$ \\
\hline NT & $\begin{array}{l}\text { Chief Minister's Department } \\
2012 \text { Ceased }\end{array}$ & $\begin{array}{l}\text { Henderson } \\
\text { Mills }\end{array}$ & $\begin{array}{l}\text { ALP } \\
\text { LNP }\end{array}$ & Chief \\
\hline
\end{tabular}

Party Key: ALP = Australian Labor Party (Left of Centre) LIB = Liberal Party (Right of Centre) LNP = Liberal National Party (Right of Centre)

Although similar in structure in many respects, the Australian state plans have been created largely in the absence of open cooperation or acknowledgement of any other state's plan as a model. Each jurisdiction in effect 'invented its own wheel' and each plan has an impression of being created locally for its own situation, resulting in clear variations in each of the eight jurisdictions' models.

In varying degrees and means, each of the state plans show evidence of all or some of the recognised benefits of the strategic planning approach, as outlined by Bryson (2010a: 255):

- Promotion of strategic thinking, acting, and learning (e.g., understanding context, clarifying mission, figuring out what strategies are best, negotiating performance measures and standards, building needed coalitions of support)

- Improved decision making (e.g., making decisions tied to organizational purposes and in light of future strategic consequences)

- Enhanced organizational effectiveness, responsiveness, and resilience (e.g., meeting mandates, fulfilling mission, improved overall coordination and integration, better performance control, satisfying stakeholders according to their criteria, adapting to environmental changes)

- Enhanced effectiveness of broader societal systems (e.g., collaborating with others, often across sector boundaries, to address broad public problems)

- Improved organizational legitimacy (e.g., based on satisfying key stakeholders and creating real public value at reasonable cost)

- Direct benefits for the people involved (e.g., human and social capital building, improved morale, fulfilment of job responsibilities, improved competency, enhanced job prospects, reduced anxiety). 
The absence of a template does not altogether rule out any form of imitation. Anecdotal evidence points to at least a casual level of policy learning resulting from Premiers, their senior personnel and departmental staff mingling and informally exchanging views at COAG meetings and other fora. ${ }^{3}$ In addition, TAS and SA both prominently acknowledged direct policy learning from the now defunded Oregon Shines model - one of the pioneers of state plans in the USA (Oregon 1989-2009). The SA government employed Jeff Tryens, the Oregon Shines executive director, as a consultant in an open and concrete display of this link.

The state plans do demonstrate a number of similar structural features and policy areas for attention. The first commonality stems from the fundamentally similar functions of State and Territory governments, in that state plan key strategic goals distil the core concerns of State and Territory governments in an administrative, policy and political sense. These include, albeit in differently badged forms (variously labelled 'visions', ‘strategic goals’ or 'objectives'): economic growth, infrastructure, health, education, community safety and well-being, and environmental sustainability (for two current examples, see the five strategies for NSW 2021 in Box 1 and the six priorities of SA's Strategic Plan [SASP] in Box 2).

The second common feature is that all plans, with the exception of WA's, break the key strategic goals down further into outcomes which have both measurable and reportable targets for performance (see Table 2 and Box 1 and 2), ranging from a low of 10 for QLD's state plan and a high of 212 targets for TAS's original state plan (see Table 1). The number of outcomes indicates the breadth of the plan across government, while the ratio of outcomes to visions intimates the level of detail of administrative linkages between the broad vision and the specific targets. The current NSW plan, NSW 2021, for example, is very detailed and comprehensive with 36 outcomes (or targets) per strategy (or 180 targets in total, with more than 280 listed measures); by contrast, QLD’s Q2 was much more broad-brush with just two targeted measurable outcomes for each of its five visions, or 10 outcomes in total.

Table 2: State Plans Strategy to Benchmark Ratios

\begin{tabular}{|l|l|l|}
\hline State/Territory and Plan Title & $\begin{array}{l}\text { Year Plan Implemented/ } \\
\text { Updated/Strategies/Goals }\end{array}$ & Benchmark/Outcome per Strategy (n) \\
\hline
\end{tabular}




\begin{tabular}{|c|c|c|}
\hline TAS Tasmania Together & $\begin{array}{l}200142 \text { Strategies } \\
200612 \text { Strategies } \\
200912 \text { Strategies }\end{array}$ & $\begin{array}{l}5.0(212) \\
11.9(143) \\
12.5(151)\end{array}$ \\
\hline $\begin{array}{l}\text { VIC Growing Victoria } \\
\text { Together }\end{array}$ & $\begin{array}{l}20013 \text { Strategies } 11 \text { Goals } \\
20055 \text { Strategies } 10 \text { Goals } \\
\text { (Ceased 2011) }\end{array}$ & $\begin{array}{l}14.0(42) \\
7.2(36)\end{array}$ \\
\hline $\begin{array}{l}\text { WA Better Planning Better } \\
\text { Services (2003) Better } \\
\text { Planning, Better Future } \\
\text { (2006) State Sustainability } \\
\text { Strategy 2003-2008 }\end{array}$ & $\begin{array}{l}20035 \text { Strategies } \\
20065 \text { Strategies } \\
\text { (Ceased 2008) }\end{array}$ & $\begin{array}{l}14.4(72) \\
4.2 \quad(21) \\
-\end{array}$ \\
\hline $\begin{array}{l}\text { SA South Australia's } \\
\text { Strategic Plan }\end{array}$ & $\begin{array}{l}20046 \text { Strategies } 14 \text { Goals } \\
20076 \text { Strategies } 14 \text { Goals } \\
20116 \text { Strategies } 14 \text { Goals }\end{array}$ & $\begin{array}{l}14.0(84) \\
16.3(98) \\
16.6(100)\end{array}$ \\
\hline ACT The Canberra Plan & 2004 & $4.0(28)$ \\
\hline $\begin{array}{l}\text { QLD Smart Queensland: } \\
\text { Smart State Strategy 2005- } \\
2015 \text { (2005) Smart State } \\
\text { Strategy: Queensland's Smart } \\
\text { Future 2008-2012 (2008a) } \\
\text { Toward Q2: Tomorrow's } \\
\text { Queensland } \\
\text { (2008b) }\end{array}$ & $\begin{array}{l}20055 \text { Strategies } \\
20085 \text { Strategies } \\
\text { (Ceased 2012) }\end{array}$ & $\begin{array}{l}2.0(10) \\
2.0(10) \\
-\end{array}$ \\
\hline $\begin{array}{l}\text { NSW (1) NSW State Plan: A } \\
\text { New Direction for NSW } \\
\text { (2006) NSW State Plan: } \\
\text { Investing in a Better Future } \\
\text { (2010) }\end{array}$ & $\begin{array}{l}200614 \text { Strategies } 34 \text { Goals } \\
20107 \text { Strategies } 44 \text { Goals } \\
\text { (Ceased 2011) }\end{array}$ & $\begin{array}{l}4.2(60) \\
12.8(90) \\
-\end{array}$ \\
\hline NSW (2) NSW 2021 & 20115 Strategies 32 Goals & $36.0(180)$ \\
\hline NT Territory 2030 & $\begin{array}{l}20096 \text { Strategies } 21 \text { Goals } \\
\text { (Ceased 2012) }\end{array}$ & $21.3(128)$ \\
\hline
\end{tabular}

A third common feature is that state plans are used specifically to provide direction and act as an organising device for individual agency budget allocations, programs and performance measures, along with departmental strategic plans more generally. This is aimed at ensuring that there is alignment and strategic fit between agency priorities and activities and the overall strategic direction set by government. For example, the SA target of increasing student reading, writing and numeracy results can be traced back to the relevant priority, vision and goal to departmental target levels and further to school target levels (Box 2). Achieving this detail in tracking outcomes across all areas of government activity is problematic. Indeed, it is acknowledged in NSW 2021 as a significant undertaking in itself and an incremental work in progress rather than a settled and operationalised achievement (Government of NSW 2011:4).

\section{Box 1: Examples of Detail from State Plans - NSW}


Time horizon: 2021.

Five Strategies: - Rebuild the Economy - Return Quality Services - Renovate Infrastructure -

Strengthen our Local Environment and Communities - Restore Accountability to Government.

Example:

Strategy (2 of 5): Return Quality Services - provide the best transport, health, education, policing, justice and family services with a focus on the customer (Contains 12 Goals, numbers 7 to 18 of 32). Goal 15: Improve Education and Learning Outcomes for all Students. (Contains 6 Targets of 180). Target (1 of 6 for Goal 15): All children in NSW have access to a quality early childhood education program in the 12 months prior to formal schooling by 2013.

\section{Box 2: Examples of Detail from State Plans - SA}

\section{SA’s Strateqic Plan 2011 (Year released 2011)}

Time horizon: 2020.

Three Organising Priorities: - Our Community - Our Prosperity - Our Environment.

Three Additional and Essential Priorities: - Our Health - Our Education - Our Ideas.

Goals and Priorities: Our Community; 22 Goals - Our Prosperity; 9 Goals - Our Environment; 12 Goals

- Our Health; 4 Goals - Our Education; 5 Goals - Our Ideas; 4 Goals.

Fourteen Visions: - Our Communities are vibrant places to live, work, play and visit - Everyone has a place to call home - Strong families help build communities - We are safe in our homes, community and at work - We are connected to our communities and give everyone a fair go - A strong, sustainable economy that builds on our strengths - We have a skilled and sustainable workforce - SA plans and delivers the right infrastructure - South Australians think globally, act locally and are international leaders in addressing climate change - We look after our natural environment - We value and protect our water resources - We are active in looking after our health - South Australians are the best teachers and learners - South Australians are creative; we innovate to overcome environmental, economic, and social challenges.

\section{Example:}

Priority (5 of 6): Our Education

Vision (13 of 14): South Australians are the best teachers and learners. (Contains 5 Goals [48-53] and 7 Targets [87-93]).

Goal (48 of 56): We are the best educated in the nation.

Target (87 of 100): Reading, writing and numeracy: By 2020, for reading, writing and numeracy, increase by five percentage points the proportion of South Australian students who achieve - above the National Minimum Standard - higher proficiency bands (baseline: 2008.)

A fourth common feature is that most state plans involve community consultation and general engagement as a part of the initialising design and continuing monitoring 
processes. They operate with varying degrees of comprehensiveness and 'bottom-up' or top-down' orientation, from extensive the consultation of TT, to the more limited approaches of GVT and SASP (as critiqued by Nabben 2011 and Manwaring 2010 respectively). These processes include inputs for citizen comment and feedback via a dedicated web-site, social media, free 1300 phone access numbers, comment pre-paid postcards, forums and meetings physically spread across the state or territory and held periodically and most particularly in the initial design and subsequent set review phases. ${ }^{4}$

Fifthly, a common feature to note is the crucial role of the core executive of government. With the exception of TAS, which had an independent statutory body managing TT until December 2012, the administration of state plans is conducted by the Premier's or Chief Minister's Department with the direct personal involvement of the Premier or Chief Minister in the key decision processes and also the involvement of the leader's personal office and departmental senior staff (as TT now does).

In all cases, the imprimatur of the Premier or Chief Minister at the time of instigation was essential to the plan's progression and these leaders were generally heavily publicly identified as promoters of the plan (again with the exception of WA, where the two plans were low key in terms of public promotion). The most recent state plan, NSW 2021, is an example of this. Tagged as ‘Barry’s Bible’ for its close association with Premier O'Farrell, it was reported that in the cabinet committee headed by the Premier and the Deputy Premier, they will 'grill ministers and department heads on their targets. "The 32 priorities in the plan should be on every minister's pinboard and a copy of the plan in every briefcase”' (Aston 2011).

NSW 2021 is (to date) unique as the only non-Labor government state plan. NSW shares with TAS (the 1998 election of the Bacon Labor government), VIC (the 1999 election of the Bracks Labor government) and SA (the 2002 election of the Rann Labor government), the characteristic of being created soon after a partisan change of government. In each of these examples, the creation and operation of the state plan was emblematic of a new direction for the government and as such, a departure from the modus operandi of the previous government. For example, the Bracks government used the state plan to signify a major break from what it considered to be the excesses of the Kennett government's economic rationalist approach (Adams and Wiseman 
2003). Similarly, four of the strategies of the O'Farrell plan are tagged with the transitive verbs rebuild, return, restore and renovate and are clearly meant as reminders of deterioration under the previous Labor government and a change of direction under the new administration.

In other cases, introduction or revision of a state plan was associated with a change of leadership within an existing government, to demonstrate a new direction and refreshed approach (for example the leadership changes to Iemma and Keneally in NSW, Bligh in QLD Henderson in NT and most recently Giddings in TAS).

Finally, the generalised state plan process follows a similar cyclical pattern in all jurisdictions: after initial instigation by the core executive, the plan passes through phases of community consultation, implementation and management to a regular review commonly held every two years (with an annual reporting requirement also included), and the adoption of a new revised plan (or, in some cases, termination).

The cyclical process results in updates and improvements to the plans, partially as a direct reflection of community input to the review process, as for example with the three iterations of TT and SASP.

\section{Managing, Monitoring and Marketing}

As previously noted, the three strategic orientations we identify of managing, monitoring and marketing may be competing, complementary or overlapping. They compete as primary orientation where, for example, the component of the core executive responsible for media and image management (the government media offices generally in Premier/Chief Minister's offices or departments) may seek to promote marketing as the primary orientation, while Treasuries may promote the monitoring orientation and Premier/Chief Minister's departments and public sector management agencies focus on the managing orientation.

This may also result in the three orientations overlapping and complementing each other, where elements of all three are evident to some degree. To follow on from the example above, marketing the government of the day may also accurately depict 
success in the overall managing and monitoring of programs and thereby builds community confidence and engagement with government.

Orientations can understandably vary between the different plans as local conditions differ and also across time. At different stages of the electoral cycle, governments may concentrate more on one of the three (such as marketing the initial plan to signal the new direction of the recently elected government, or marketing the government's successes close to the next election). There may also be variation according to topical development; for example if a program suffers from management deficiencies, then managing will come to the fore as a concern.

There can also be variations in orientation according to stakeholder perspectives. Internal stakeholders such as public servants involved in service delivery may be more concerned with monitoring actual performance and using the state plan as a key management reference for their activities (and may indeed have their own key performance indicators (KPIs) set against the plan’s targets).

External stakeholders such as key interest groups, the media or the 'interested public', may be more concerned with the integrity of the monitoring function, so they can see how the plans contribute to (or detract from) their perception of and confidence in government. External stakeholders may also respond positively to ongoing consultation and monitoring directly involving them (Bozeman and Straussman 1990).

Like governments, both internal and external stakeholders will fluctuate in their attention towards performance and perception of the plan. The task for the core executive is to balance its own multiple goals for the plan with the expectations of its key stakeholders.

Elements of each of the three orientations can be found in almost every one of the state plans produced to date. Taking the example of the NSW 2021 excerpt in Box 1 above, the strategy of 'return quality services - provide the best transport, health, education, policing, justice and family services with a focus on the customer' has a strong political marketing message and management improvement component. The goal 'improve education and learning outcomes for all students' is designed to 
improve a public good and to build social confidence that this can be achieved, while the target for 'all children in NSW [to] have access to a quality early childhood education program in the 12 months prior to formal schooling by 2013' is a concrete one that will either be achieved (and thus become a marketing and management plus for the government) or not. The measurement of this will depend on the strength of the monitoring process. The following is a concise discussion of the significant features of each of the three orientations.

\section{Managing}

As noted earlier, strategic planning does not necessarily imply the practice of strategic management but it is conditional on the former already being in place. In the strategic management context and from a top down perspective, state plans act as a management tool for the core executive of Premier/Chief Minister and Cabinet and strategic level leadership in the core agencies of bureaucracy, to seek control and direction over bureaux and programs. Taking a whole-of-government and whole-ofprogram approach, the state plans provide a platform for drilling from the macro level of government portfolios (the strategic visions or goals) through the meso level of organisational units (priorities or objectives) down to the micro level of actual service provision (benchmarks or targets).

Adams and Wiseman also found managerial benefits (of GVT) in enhancing the policy skills of the public service via 'learning about different approaches to policy development (e.g. moving from risk management to managed risk taking); policy development techniques (for example community consultation and scenario planning strategies) and new understandings of the relation between policy issues (the implications of new thinking about sustainability and triple-bottom-line approaches)' (2008:19).

The state plan approach pulls government in a different direction from the disaggregated trends of some iterations of NPM, where central control was diluted yet the political fallout for problems was not; in that Ministers and Premiers would be criticised for aspects of administration they had little influence over. The state plan approach aggregates government into one accountable, manageable and coherent entity (Gallop 2007). 
A potentially crucial management role for state plans is to ensure cross-agency issues do not 'fall between the cracks' and for responsibility for each targeted area to be specifically assigned to an agency. Furthermore, individual CEOs can be questioned about (and rewarded or penalised for) the extent to which they are planning for and achieving specific targets contained within the state plan and this can form a crucial part of their own KPIs. This has explicitly been applied in both SA and NSW.

There are potential pitfalls in the utility of state plans as a management tool. A significant issue is that of the number of targets and objectives - as we have seen, QLD’s Q2 plan had just 10, while NSW and TAS at times have had over 200. If there are too few targets, then whole areas of government are potentially left without direction or an explicit mandate from their political masters, and there is a risk of agency strategic plans being made in a policy vacuum, of policies being at crosspurposes, or of agencies 'going rogue' (in the view of the core executive).

On the other hand, if too many objectives are set, then prioritisation - an essential element of good management - becomes virtually impossible, and the potential for an approach where 'all targets are equal' arises (noted below in the monitoring context). This concern was explicitly raised by the NSW Parliament's Report on State Plan Reporting which recommended government review the number 'of targets to ensure they prioritise the urgent and important rather than elevating the routine' (Public Accounts Committee [NSW] 2008).

\section{Monitoring}

The first wave of the public management change that later became a component of NPM was concerned with improving the information collected and reported on the use of financial and human resources. The widely deployed axiom of performance management is 'what you can't measure, you can't manage' as there is an inexorable need to track performance to build on success and reduce failure, as well as enabling improved accountability for achieving outcomes.

Monitoring is a pre-condition for strategic planning. Bryson, for example, delineates strategic planning as being based on 'broad scale yet effective information gathering, 
clarification of the mission to be pursued and the issues to be addressed along the way, development and exploration of strategic alternatives, and an emphasis on the future implications of present decisions' (Bryson 2010b:6). Prior to embarking on state plans, the States and Territories had already paid significant attention to and built generally sound systems for monitoring financial, personnel and performance management through a raft of financial administration and audit acts, the introduction of accrual accounting, new techniques such as balanced scorecard approaches and a shift from input measurement to output and outcome measurement.

All of these advances were made possible by the rapid uptake of and improvement in speed and capacity of information and communication technology, through which the amount of data that could be stored and then rapidly and accurately retrieved increased exponentially. Other important changes in the monitoring of government emerged in the same period, including increased scope for auditors and the introduction of freedom of information acts, requiring by law that records be accessible. The improved monitoring of human resources, of set performance indicators for agencies, sub-sections and individuals within them was also subject to a considerable advance in this period. Although there have been slip-ups in the monitoring process identified by auditors general in the States and Territories, the general trend has been one of considerable improvement and this has been separate from any state plan processes in place.

With the adoption of state plans, however, several further innovative measures were introduced:

- In all cases, state plans have brought government policy targets together into one document, making it easier for all to see what government is aiming to do, and to compare progress across policy areas;

- State plans incorporate whole of government targets (as distinct from agencyspecific ones). This potentially increases the ambition of government and brings more significant cross-government or longer-term problems into view;

- Public participation has (despite its critics) injected a 'popular' element into both the choice of target areas as well as the specific target parameters chosen;

- In some cases (for example, TAS), external monitors have been introduced, and in most cases a regular reporting period has been prescribed, exposing 
government to ongoing media and public scrutiny, thereby increasing public accountability.

However, the target-setting process is also prone to criticism. Targets may be seen as being too easy or too distant (for example, pushing achievement deadlines beyond the next election). There is also the issue of prioritisation as there may be a tendency for governments to claim good progress overall if most targets are on-track, even if a few 'core' targets (which may be more important to the media or the public) receive negative ratings.

\section{Marketing}

Although broadening as a concept for over four decades (Kotler and Levy 1969), marketing has often been viewed pejoratively in organisational environments associated with, or heavily influenced by, political processes. However, marketing in public management generally and state plan cases specifically is potentially far wider than the media management spin of political marketing. It can also include other marketing processes such as marketing of place (the marketing of the State as a place to live, work, tour, invest in and so forth) and social marketing (seeking to inform and engage with citizens to change their behaviours in the pursuit of an improved public good).

Taking the political marketing orientation first, it is almost a natural consequence of contemporary political conditions for core executives of governments to seek to manage their media image and to use the resources available to them to gain advantage over oppositions in terms of public perception. In addition, as has been noted above, in virtually every case, the introduction of state plans was associated with the election of either a new government or the appointment of a new leader, and these leaders were keen to use the plans as a way of marketing themselves and their government's new directions and achievements.

It is no surprise then that a common criticism of state plans in several jurisdictions is that they are primarily orientated in purpose towards political marketing, using public funds to promote the government of the day. Often regarded as blatant 'spin' exercises, they attracted critical headlines such as 'ALP spent $\$ 160,000$ on research', 
'Labor 'talkfest' cost us \$84,000' (The Age on GVT); 'Bill for taxpayer-funded ads tops \$10 million’ and ‘Hard sell: Iemma’s \$2.6m campaign to spruik state plan’ (The Sydney Morning Herald on NSW State Plan; see Baker and Hannan 2002; Clennell 2006; Hannan 2001a; 2001b; Pearlman 2006).

Manning characterised SA Premier Mike Rann's style as being that of a 'king of spin', but then also noted Rann's own recognition of the potential for SA's Strategic Plan to be 'a rod for our own back' in that failing to achieve targets would result in negative scrutiny and publicity (Manning 2005:217). Indeed, state plans potentially provide oppositions and media with easy access to packaged information, which can be used, for attacks on perceived failures in government administration, instead of requiring the more resource and time-consuming accountability routes such as parliamentary questions and committee work, Freedom of Information requests, investigative journalism and the like. This political marketing hazard is also a likely cause for WA’s low key state plans, despite Premier Gallop’s (see Gallop 2006, 2007) own enthusiasm before and after - but not in - office, for strategic planning, as noted by van Schoubroeck (2008, 2010).

In a different political marketing approach, QLD’s state plan emerged out of the Beattie government's initial branding of QLD as the 'Smart State' - an exercise in marketing of place that can be traced back to the post-1998 election period. 'Smart State’ did not metamorphose into a formal state plan, Smart QLD: Smart State Strategy 2005-2015, until 2005. As one critical commentator observed, the 'Smart State slogan was a good idea that was bastardised because it was attached to even the most mundane activities of the Beattie administration' (Wardill 2011). The same commentator noted that in the lead up to the 2012 state election, the successor strategy Toward Q2: Tomorrow's $Q L D$, did not take a high profile in promoting the government (and thereby failed as a political marketing strategy) as it had 'become all but invisible' and 'was always lofty motherhood statements rather than stringent targets ... the question now has to be asked whether it was more about branding Bligh than guiding the Government' (Wardill 2011).

Despite the undoubted use of state plans for political marketing, they have also demonstrated aspects of 'place' and 'social' marketing. In the context of Australia's 
federal arrangements, where the States and Territories are competitors with each other as well as globally for competitive advantage, bringing key information about a State or Territory into a coherent and easily accessed form, both via the web or in glossy brochures that each of the state plans has produced, is an important asset. State plans also provide many opportunities for government to adopt social marketing by communicating directly with citizens, to build and reinforce social capital through community participation, and even to promote public good outcomes in those parts of the state plan addressing specific policy areas and program portfolios. Allied to the management orientation discussed above, using a state plan as a key platform for social marketing acts against disaggregated, confusing or conflicting campaigns and creates a one-stop-shop entry point for citizens.

\section{Conclusion: Getting the Managing, Monitoring and Marketing Balance Right}

State plans originated under Labor governments in power for most of the 2001-2011 decade and could be seen as inherently partisan Labor vehicles with an emphasis on top-down planning rather than as neutral instruments for use by either side of politics. A key test of this issue was whether they could survive a change of government. In WA, VIC, QLD and NT, coalition election victories have seen the incoming governments quickly abandon the plans that were in place. The exception is the O'Farrell coalition government's creation of and strong commitment to NSW 2021; it is therefore reasonable to expect that the state plan experiment will continue for some time to come in at least one conservative jurisdiction. Although TAS's TT legislation was repealed in 2012, given the Opposition's current supportive policy position discussed above it is likely that TT would survive a change of government there; the position in SA and ACT is less certain.

It also remains possible that NSW 2021, if demonstrably efficacious, could act as a spur for further policy learning and result in renewed state plan efforts in the jurisdictions that have abandoned plans or encourage others to re-badge and restructure plans rather than discard them. As noted above, the monitoring orientation of the plans is something that is already occurring within government and will undoubtedly continue to occur in all jurisdictions whether set into a state plan and made readily publicly accessible or not. 
Also the managing orientation is evident in a strategic sense, where core executive agencies, especially Premier’s and Chief Minister’s departments, seek to extend effective control over all aspects of government administration made possible via the information available through the monitoring process, whether this is via a state plan vehicle or through budgetary, mandatory reporting, auditing and other administrative mechanisms.

The marketing orientation, in terms of political marketing, marketing of place (in a competitive federal environment) and social marketing, is perhaps the key consideration in whether a state plan will be adopted or not. As strategic monitoring and managing takes place regardless, bringing all of the processes together via a state plan is an opportunity to market a jurisdiction and its administration. Politically this is a two-edged sword. A state plan, especially where readily available, openly communicated and provided in interactive web form, is a means for citizens to track government activity in an instantaneous and unmediated way, achieving social marketing outcomes. On the other hand, it allows oppositions, media and critics of governments a means to relatively effortlessly highlight failures and problems.

Balancing these managing, monitoring and marketing orientations is an ongoing and unavoidable concern of core executive government and may lead to further experimentation with strategic planning in whole-of-government and jurisdictionwide contexts. Further scrutiny of past and existing state plans is warranted to both record and review a significant development in Australian public management practice and also to further explore prospective application of the concept.

\section{Endnotes}

1. The latter was re-titled and modified in 2006 to Better Planning, Better Futures.

2. It could be argued that Victoria had effectively discarded Growing Victoria Together under Premier Brumby by the time of the election in late 2010, which saw the Labor government defeated and the formal abandonment of GVT by the incoming coalition government. 
3. In addition, the NT explicitly borrowed from the expertise and experience of SA in adopting its Territory 2030 plan (personal communication with SA Department of Premier and Cabinet officer).

4. WA was the main exception to this, with its Better Planning, Better Services being a wholly internally generated document. WA's State Sustainability Strategy had more public involvement (as well as measurable goals), but it never had the official status of a formally sanctioned state plan which departments were obliged to follow.

\section{References}

Adams, D. and Wiseman, J. 2003. 'Navigating the Future: A Case Study of Growing Victoria Together.’ Australian Journal of Public Administration 62:2 11-23.

Althaus, C. 2008. Calculating Political Risk. Sydney: University of NSW Press.

Aston, H. 2011. 'Barry's bible: the word is jobs.' The Sydney Morning Herald 4 September.

Baker, R. and Hannan, E. 2002. 'ALP spent \$160,000 on research.' The Age. 6 November.

Bozeman, B. and Straussman, J. 1990. Public Management Strategies. San Francisco: Jossey-Bass.

Brueckner, M. and Pforr, C. 2011. 'The rise and fall of sustainability in Western Australian politics: a review of sustainability under the Western Australian Labor government between 2001 and 2008.' Sustainability: Science, Practice \& Policy. (7)2: 3-17.

Bryson, J. 2010a. 'The Future of Public and Nonprofit Strategic Planning in the United States.' Public Administration Review December 2010. Special Issue.

Bryson, J. 2010b. Strategic Planning for Nonprofit Organizations $3^{\text {rd }}$ Ed. San Francisco: Jossey-Bass. 
Clennell, A. 2006. 'Bill for taxpayer-funded ads tops \$10m.' Sydney Morning Herald 22 August.

Coffey, B. and Major, A. 2005. 'Towards More Integrated Natural Resource Management in Victoria: Possible Elements of an Integrated State-wide Policy Framework.' Australian Journal of Environmental Management 12: 29-38.

Crowley, K. 2006. 'Participatory Policy-Making for Sustainability.' In Beyond the Policy Cycle: The policy process in Australia, ed. H. K. Colebatch. Sydney: Allen \& Unwin.

Crowley, K. 2009. 'Can Deliberative Democracy be Practised? A Subnational Policy Pathway.' Politics \& Policy 37:5 995-1021.

Crowley, K. and Coffey, B. 2007a. 'New Governance, Green Planning and Sustainability: Tasmania Together and Growing Victoria Together.' Australian Journal of Public Administration 66(1): 23-37.

Crowley, K. and Coffey, B. 2007b. 'Tasmania Together and Growing Victoria Together: Can State Plans Deliver Environmental Sustainability? Public Administration Today 10 (January-March): 48-60.

Dunleavy, P. and Rhodes, R. 1990. 'Core Executive Studies in Britain’ Public Administration 68 (Spring): 3-28.

Gallop, G. 2006. 'Best strategy for state plan is to give it time and money.' The Sydney Morning Herald. 22 August.

Gallop, G. 2007. 'Strategic Planning: Is it the New Model?’ Public Administration Today 10 (January-March): 28-33.

Government of the Australian Capital Territory. 2004, 2008. 'The Canberra Plan.' http://www.cmd.act.gov.au/canberraplan 
Government of New South Wales. 2006, 2009. 'NSW State Plan.'

http://more.nsw.gov.au/stateplan

Government of New South Wales. 2011. 'NSW 2021'www.2021.nsw.gov.au

Government of the Northern Territory. 2009. 'Territory 2030.'

http://www.territory2030.nt.gov.au/

Government of Queensland. 2005. 'Smart State Strategy.'

http://www.smartstate.qld.gov.au/

Government of Queensland. 2008. 'Q2.'

http://www.towardq2.qld.gov.au/tomorrow/index.aspx

Government of South Australia. 2004, 2007. 'SA’s Strategic Plan.'

http://www.saplan.org.au/

Government of Tasmania. 2001, 2006. 'Tasmania Together.'

http://www.Tasmaniatogether.tas.gov.au/

Government of Victoria. 2001, 2005. 'Growing Victoria Together'

http://www.dpc.vic.gov.au/CA256D8000265E1A/page/Growing +Victoria+Together!O

penDocument $\& 1=30-$ Growing + VIC + Together $\sim 2=\sim \& 3=\sim$

Government of Western Australia. 2003a. 'State Sustainability Strategy.'

http://www.dec.wa.gov.au/content/view/3523/2066/

Government of Western Australia. 2003b. 'Better Planning, Better Services.'

http://www.publicsector.wa.gov.au/Pages/ArchivedPublications click on 'B': aspx .

Government of Western Australia. 2006. 'Better Planning, Better Futures.'

http://www.publicsector.wa.gov.au/Pages/ArchivedPublications.

Hannan, E. 2001a. 'Labor 'talkfest’ cost us \$84,000.' The Age. 30 April. 
Hannan, E. 2001b. 'Bracks to declare blueprint for state.’ The Age. 23 November.

Hughes, O. 2003. Public Management and Administration: An Introduction.

Houndmills: Palgrave MacMillan.

Kotler, P. and Levy, S. 1969. 'Broadening the Concept of Marketing.' Journal of Marketing, 33(1): 10-15.

Manning, H. 2005. 'Mike Rann: A Fortunate ‘King of Spin.’ In Yes Premier: Labor Leadership in Australia's States and Territories. Wanna, J. Williams, P. Eds.

Sydney: University of NSW Press.

Manwaring, R. 2010. 'Unequal voices: 'Strategic’ Consultation in South Australia.' Australian Journal of Public Administration 62(2): 178-189.

Nabben, R. 2011. 'Opportunity Lost? Victorian Labor's Enactment of Community Development 1999-2006.' Australian Journal of Public Administration 70(3): 287297.

Newell, C. and Wilkinson, R. 2003. 'Tasmania Together? A disability critique of a social plan.’ Disability \& Society 18(4): 458-470.

Nutt, P. Backoff, R. 1987. 'A Strategic Management Process for Public and ThirdSector Organizations.' Journal of the American Planning Association, 53(1): 44-57

Oregon 1989-2010 ‘Oregon Shines’ Benchmark Performance Reports. http://www.oregon.gov/DAS/OPB/os.shtml\#Oregon_Shines_1989 Accessed 16/11/10.

Pearlman, J. 2006. ‘Hard sell: Iemma’s \$2.6m campaign to spruik state plan.' Sydney Morning Herald. 16 November. 
Public Accounts Committee (NSW). 2008. Report on State Plan Reporting. New South Wales Legislative Assembly Public Accounts Committee.

van Schoubroeck, L. 2008. 'Strategic Planning: Why Would Politicians Be Interested? Some Insights from Western Australa.' Canadian Political Science Association Annual Conference, Vancouver, 6 June.

van Schoubroeck, L. 2010. The Lure of Politics: Geoff Gallop’s Government 20012006. Crawley: University of WA Press.

Wardill, 2011 'Sad state of affairs as Q2 vision fades.' The Courier Mail 16 April. 